\title{
POSZUKIWANIE ZNACZEŃ SZTUKI NASKALNEJ NA PODSTAWIE BADAŃ POŚWIĘCONYCH WSPÓŁCZESNEJ TWÓRCZOŚCI DZIECI
}

\author{
LOOKING FOR THE MEANINGS OF ROCK ART THROUGH \\ THE RESEARCH ON CONTEMPORARY CHILDREN'S ART
}

\author{
Marek Pankiewicz \\ ul. Newtona 6D/18, 60-161 Poznań, Polska \\ marek.pankiewicz@hotmail.com
}

\begin{abstract}
Child art has long been a subject of research. Books and papers on the issue inspired me to look at rock art through the prism of studies on the artistic works of the little ones. This paper discusses a pilot study that I have conducted and offers some theoretical considerations on reading art.
\end{abstract}

KEY WORDS: rock art, children's art, pilot study, interpretation of rock art

\section{WPROWADZENIE}

Od początku zainteresowania tematem sztuki naskalnej nieodłącznie towarzyszy nam poszukiwanie jej znaczenia (Rozwadowski 2009, s. 80-159; Clottes, Lewis-Williams 2009, s. 90-113). Ma to swoje odzwierciedlenie w debacie naukowej poświęconej teoriom na temat powyższego zagadnienia, nazwie dyscypliny, problematyce związanej z datowaniem, metodach i technikach dokumentacyjnych.

W 2007 r. zacząłem interesować się szerokim zagadnieniem, jakim jest sztuka naskalna. Odkąd pamiętam, fascynował mnie temat znaczenia naskalnych przedstawień. Przypadek sprawił, że natrafiłem w internecie na informację prasową poświęconą działalności naukowej Małgorzaty Karczmarzyk. Autorka zachęcała w niej do odkrywania wielości znaczeń rysunku dziecka i traktowania jego twórczości jako swoistej sztuki. 
Opisana problematyka wydała mi się zbieżna z zagadnieniami dotyczącymi sztuki naskalnej. Zaowocowało to poszukiwaniem literatury w tym zakresie. Zapoznanie się z nią utwierdziło mnie w słuszności moich spostrzeżeń i doprowadziło do przeprowadzenia badania pilotażowego w sierpniu $2012 \mathrm{r}$.

Celem artykułu jest pokazanie, na podstawie wybranych zagadnień teoretycznych omawiających problematykę twórczości dzieci i badania pilotażowego, jak wiele elementów ma wpływ na kształtowanie i odbiór znaczeń sztuki, a co się z tym wiąże sztuki naskalnej. Tekst ten ma też potwierdzić sens przenoszenia zagadnień poświęconych dziełom najmłodszych na grunt sztuki naskalnej.

Publikacje poświęcone sztuce naskalnej jeśli już poruszają problematykę ,dziecięcą", to w kontekście dostrzeżenia w dziełach z przeszłości takich, które można by przypisać małym autorom. Wyjaśniają i przybliżają one zagadnienia związane z tą tematyką młodym ludziom, a także informują o programach edukacyjnych skierowanych do najmłodszych (Consens, Bello, Rodríguez 2002, s. 69-76; Cue Villate, Fernandez Ortega 2006; Jolly 2003, s. 17-18). Na podstawie przeprowadzonych badań uważa się, że prawdopodobne jest, aby to dzieci były autorami „finger flutings", a także przedstawień polegających na odcisku kończyn czy używaniu ich jako szablonów (Bednarik 2008, s. 173-182; Bower 2007, s. 264-266; Sharpe, Lacombe, Fawbert 2002, s. 109-116; Sharpe, Van Gelder: 2004a, s. 9-17; 2004b; 2005, s. 68-74; 2006a, s. 937-947; 2006b, s. 179-198; 2006c, s. 281-295; 2010, s. 269-285; Stapert 2007; Van Gelder 2012).

Z powodu tego, że cel mojej pracy jest zupełnie inny, powyższe przywołuję tylko w roli informacyjnej, zaznaczając, że tematyka „dziecięca” już funkcjonuje w literaturze przedmiotu na innych płaszczyznach rozważań.

\section{BADANIE PILOTAŻOWE}

Celem badania było sprawdzenie, czy zajęcia z dziećmi i zagadnienia dotyczące znaczeń ich rysunków mogą być istotne dla studiów nad sztuką naskalną, potwierdzając tym samym podobne problemy dostrzeżone na podstawie literatury analizującej rysunki współczesnych dzieci i mojej wiedzy w zakresie sztuki naskalnej.

Badanie pilotażowe zostało przeprowadzone 17 sierpnia 2012 r. w Muzeum Archeologicznym w Poznaniu. Odbyło się ono za zgodą i dzięki uprzejmości dyrekcji tej placówki ${ }^{2}$. Zajęcia pt. „I Ty możesz zostać badaczem sztuki naskalnej!” zostały przeprowadzone w małej sali dydaktycznej i na wystawie stałej pt. „Sztuka Naskalna Afryki Północnej”.

\footnotetext{
${ }^{1}$ Lub finger tracings, tracés digitaux - są to linie, ślady wykonane palcami w miękkich osadach wapiennych (mondmilch, montmilch, cave milk, leche de luna).

${ }^{2} \mathrm{Za} \mathrm{w}$ znaczący sposób ułatwienie mi realizacji projektu chciałbym podziękować: Agnieszce Mączyńskiej, Marcie Kalisz-Zielińskiej i Pawłowi Polkowskiemu.
} 
Zorganizowane zajęcia można podzielić na trzy fazy. Pierwszą, prezentacyjną, związaną $\mathrm{z}$ omówieniem podstawowych zagadnień $\mathrm{w}$ zakresie sztuki naskalnej w trakcie pokazu przygotowanego w programie „PowerPoint”; drugą, wystawową (w tej części zajęć zwiedziłem z dziećmi ekspozycję poświęconą sztuce naskalnej) i ostatnią, zadaniową, podczas której poprosiłem najmłodszych o realizację rysunkową następującego stwierdzenia: „Wyobraź sobie, że biała kartka to skała, a Ty masz jedną szansę, by coś opowiedzieć, przekazać innym - narysuj to"3.

$\mathrm{W}$ trakcie pierwszej części zajęć zauważyłem następujące reakcje najmłodszych:

- dzieci nie miały najmniejszego problemu z rozpoznaniem zwierzęcia wyrytego lub namalowanego na skale: bizona, słonia, żyrafy,

- cel powstawania tego typu przedstawień był dla nich niezrozumiały,

- dzieci nie wiedziały, czym zajmują się badacze sztuki naskalnej.

Wspólna wizyta na wystawie zaowocowała następującymi spostrzeżeniami:

- dzieci bezproblemowo rozpoznawały i nazywały ryty, jeśli nie przeszkadzał im w tym brak wiedzy, różnice kulturowe, przestrzenne,

- dla najmłodszych integralną częścią wyrytych w skałach obrazów był piasek stanowiący ich podłoże. Dzieci uważały, że jeśli na piasku powstanie rysunek, to będzie on jakby dopełnieniem rytu,

- tak jak w pierwszej części badania pilotażowego, widoczny był brak zrozumienia przez dzieci idei powstawania tego typu przedstawień.

Ostatnia faza zajęć związana była z prośbą o wykonanie rysunku realizującego temat: „Wyobraź sobie, że biała kartka to skała, a Ty masz jedną szansę, by coś opowiedzieć, przekazać innym - narysuj to". W trakcie wykonywania pracy zauważyłem:

- problem z realizacją powierzonego zadania. Na podstawie zachowania dzieci wnioskuję, że powodem tego był brak zrozumienia pierwotnej przyczyny powstawania sztuki naskalnej,

- każdy z uczestników otrzymał ode mnie poza kartką i kredkami zestaw czterech zdjęć petroglifów $\mathrm{z}$ wystawy. W trakcie sporządzania przez najmłodszych rysunków zauważyłem, że dwie dziewczynki z grupy poza realizacją powierzonego zadania kolorują rycia na fotografiach,

\footnotetext{
${ }^{3}$ Grupa zajęciowa początkowo składała się z piętnaściorga dzieci w wieku od 5 do 10 lat. W ostatniej części zajęć uczestniczyło trzynaścioro, w tym sześciu chłopców i siedem dziewczynek. Wynik jednak dotyczyć będzie tylko jedenastu prac, ze względu na to, że dwójka dzieci została odebrana przez opiekunów przed końcem zajęć.

W pierwszej i drugiej fazie badania pilotażowego obecna była trójka opiekunów, w ostatniej części jeden. Mogły te osoby wpłynąć na dzieci, a tym samym na ich realizację odpowiedzi na postawione zadanie graficzne. Zajęcia były dokumentowane zdjęciami wykonywanymi automatycznie co minutę. Widać na kilku z nich, jak opiekun pomaga w trakcie wykonywania rysunku dwójce dzieci. Z racji tego, że umknęło to mojej uwadze, nie miałem możliwości obserwacji, jaki wpływ mogła mieć ta osoba na efekt końcowy prac dzieci.
} 
- często zadawano mi pytanie, czy prace będą ocenianie. Jestem przekonany o tym, że u podłoża tego pytania leżały obawy najmłodszych przed oceną swoich prac.

Następnie, gdy dzieci wykonały już rysunki, przeprowadziłem z nimi rozmowy na temat ich prac. Każdą z nich dokumentowałem fotograficznie i wypełniałem odpowiednio wcześniej przygotowany wywiad kwestionariuszowy.

Dzieci przez rysunek wyrażają różne wartości. W przebadanej grupie zauważyłem następujące treści. Najmłodsi chcą przez rysunek podzielić się swoją wiedzą. Zaobserwowałem też zmianę znaczenia przedstawienia spowodowaną umiejętnościami osobniczymi. Rysunki pokazują z różnej perspektywy otaczającą rzeczywistość i sceny z życia. Obrazy są też zapisem marzeń autora, istotnego wydarzenia czy przedmiotu, znaku, który jest ważny dla danej osoby. W dziełach małych twórców zaznaczył się też problem ze zmieszczeniem rysunku na kartce, jak i najprawdopodobniej uwidocznił się wpływ „znaczącego innego”.

\section{TEORIE NA TEMAT TWÓRCZOŚCI DZIECIĘCEJ A WYNIK BADANIA}

Badanie pilotażowe zostało przeprowadzone na grupie dzieci w wieku od 5 do 10 lat. Na dobór grupy wiekowej miały wpływ trzy elementy. Pierwszy zakładał, aby osoby badane były w jak najmniejszym stopniu osadzone w kulturze współczesnej. Drugi element to literatura zajmująca się analizą twórczości dzieci. To ona sprawiła, że zainteresowałem się tą tematyką, a tym samym wpłynęła bezpośrednio na dobór grupy wiekowej. Trzecim elementem mającym znaczenie na dobór grupy były spostrzeżenia Władysława Strzemińskiego, który zauważa że: „istnieje duża zbieżność między widzeniem dziecka a widzeniem ludów pierwotnych oraz że świadomość wzrokowa, to znaczy zakres zjawisk dostrzeżonych przez człowieka i uświadomionych sobie przez niego, powoli narasta. U dziecka ten proces odbywa się w sposób przyspieszony wskutek nacisku otoczenia" (Karczmarzyk 2006, s. 126; Strzemiński 1974, s. 21).

Zebrany materiał badawczy był niewystarczający, aby odnieść się do spostrzeżeń Władysława Strzemińskiego.

Ze względu na to, że badanie było przeprowadzone na dzieciach, chciałbym uściślić, co będzie pod tym terminem rozumiane. Pojęcie to w tym tekście będzie definiować osoby do dziesiątego roku życia, które wzięły udział w badaniu. Nie zamierzam też tego terminu aplikować do zróżnicowanych kulturowo, przestrzenie, czasowo społeczności z przeszłości. Spowodowane jest to brakiem informacji, czy to pojęcie kiedyś funkcjonowało, a jeśli tak było, to nie wiadomo jaką grupę ludzi określało. Obecne zróżnicowanie kulturowe i przestrzenne terminu „dziecko” sugeruje, że podobnie mogło być w przeszłości. W związku z tym w artykule korzystać będę z przywołanego wyżej określenia bazującego na współczesnej definicji. 
Dzieci, tworząc „sztukę” wykonaną ,prostymi technikami”, kryją w swoich dziełach skomplikowane światy. Złożoność ich powoduje, że są dostępne dla nas tylko wówczas, gdy one nam na to w jakiś sposób pozwolą.

Twórczość dzieci najczęściej odbywa się w trakcie zabawy. „Zabawa jest dobrowolną czynnością lub zajęciem dokonywanym w pewnych ustalonych granicach czasu i przestrzeni, według przyjętych, lecz bezwarunkowo obowiązujących reguł, jest celem sama w sobie, towarzyszy jej zaś uczucie napięcia, radości oraz świadomości „odmienności” od „zwyczajnego życia” (Huizinga 2007, s. 51-52; Szczepska-Pustkowska 2008, s. 137). „Zabawa może być postrzegana jako działanie, w którym elementy wyobraźni, improwizacji oraz twórczości są co najmniej obecne" (Szczepska-Pustkowska 2008, s. 139). „W zabawach jest obecna twórczość wszędzie tam, gdzie jest miejsce dla improwizacji, przekształcania reguł zabawowych, a przede wszystkim tam, gdzie jest możliwość kreowania nowych zabaw. Z kolei w twórczości jest miejsce na zabawę wszędzie tam, gdzie tworzenie sprawia przyjemność, gdzie walka z formą jawi się artyście jako swoista złożona wieloaspektowa gra" (Golka 2004, s. 20; Szczepska-Pustkowska 2008, s. 139-140). Twórczość przeplata się z naśladownictwem w trakcie zabaw. Nie ma charakteru odtwórczego. Wyobraźnia i fantazja dzieci sprawia, że stają się one autorami pomysłów, reżyserami i aktorami. Elementy te są angażowane przez najmłodszych w trakcie zabaw tematycznych $\mathrm{w}$ tworzenie światów równoległych. Ich szczególną symbolikę można zaobserwować, gdy dzieci używają jednego przedmiotu jako symbolu innego obiektu. Zauważyć to można nawet, kiedy dziecko udaje i powiela, tworząc, w gruncie rzeczy, byty nowe. Oparte są one na rzeczywistości, nią inspirowane, na niej wzorowane, a mimo tego inne (Szczepska-Pustkowska 2008, s. 142-143). Najmłodsi $\mathrm{w}$ trakcie aktu twórczego wypracowują własne znaki. Ich dzieła są odbiciem idei kulturowych i społecznych. „Rysować, znaczy dla dziecka uczyć się używania symboli i manipulowania relacjami czy regułami wiążącymi znaczące z oznaczonym w jego otoczeniu" (Szymańska 2007, s. 199-200). Elementy takie jak symbole, reguły i otoczenie stanowić będą podstawę do indywidualnego przebiegu procesu twórczego. „Proces twórczy to bardzo osobista czynność. Rysunek dziecka stanowi projekcję jego osobowości, ale każda interpretacja pracy zależy od punktu widzenia obserwatora, jego własnych przeżyć. Dlatego tak trudno odczytać sztukę, a w szczególności tą dziecięcą" (Szymańska 2007, s. 200).

Opisane wyżej elementy znajdują swoje odbicie w zebranym materiale badawczym. Wszystkie rysunki dzieci powstały na bazie wartości ogólnie znanych w naszej kulturze. Problem z odczytaniem wypowiedzi graficznej był spowodowany unikatowym zapisem danego elementu, który wraz $\mathrm{z}$ innymi tworzył indywidualną wypowiedź. Spowodowało to, że w zebranych pracach nie ma dwóch podobnych pod względem wykonania zastosowanych elementów, ale są takie, które chcą przekazać podobne wartości. Przykładem powyższego mogą być prace siedmioletniego Patryka i jego pięcioletniego brata Kuby, którzy w swoich rysunkach m.in. chcieli podzielić 
się wiedzą na temat ryb. Poza tym elementem obie prace są od siebie zupełnie różne. Patryk narysował tylko rybę, a Kuba oprócz ryby: pingwina, konia i muszlę. Młodszy z chłopców w trakcie rozmowy i opowieści o swoim rysunku dopiero po dłuższej chwili przyznał, że starał się narysować rybę - narwala, z książki wchodzącej w skład zbioru domowego. Wcześniej przekonywał mnie, że jest to karabin za szybą. Uczynił tak ze względu na to, że w jego przekonaniu rysunek mu się nie udał. Innymi pracami reprezentującymi chęć przekazania podobnych wartości są obrazy przedstawiające wiedzę na temat otaczającej rzeczywistości, sceny z życia. Rysunki o takiej tematyce reprezentują dzieła sześcioletnich dziewczynek Małgosi i Marysi. Pierwsza z nich narysowała glob ziemski, rakietę kosmiczną na jej powierzchni, księżyc i gwiazdy. Druga natomiast ludzi siedzących lub leżących dokoła ogniska.

Thomas Pavel zastosował do teorii światów możliwych w badaniach literackich odwołanie do koncepcji make-believe. W myśl tej koncepcji świat fikcji jest zbiorem rekwizytów „umówionych” co do znaczeń między nadawcą a odbiorcą. Fantazjowanie przez dzieci w trakcie zabaw opiera się na powyższej koncepcji. Przyjąć zatem można, że najmłodsi generują wiele światów możliwych (Wasilewska 2008, s. 101). Podlegają one ,językowemu obrazowi świata”, bo dzięki językowi tworzymy społecznie zobiektywizowaną wiedzę o świecie. „Tylko w bardzo ograniczonym sensie jednostka sama z siebie wytwarza sposób mówienia i myślenia, który jej przypisujemy. Mówi językiem grupy, myśli w taki sposób, w jaki myśli grupa. Znajduje i stosuje określone słowa $\mathrm{i}$ ich sens, te zaś określają $\mathrm{w}$ dużej mierze jej dostęp do otaczającego świata" (Mannheim 1992, s. 2; Wasilewska 2008, s. 102). W związku z powyższym w kreowanych przez dzieci światach możemy odnaleźć wiedzę o autorze, jak i o grupie. Nie możemy mówić o dostępności świata fikcji ze świata rzeczywistego. Spowodowane jest to przez indywidualny, jednostkowy charakter jego kreacji. Raczej mamy do czynienia z relacjami między różnymi światami fikcji. „Artykulacja świata jest tylko transformacją jednego zapisu w inny, przemianą signifiant $\mathrm{w}$ signifié i na odwrót, pracą tekstu i pracą na tekście, obracaniem się w kręgu śladów, które pozostawiła znacząca aktywność mowy/pisma" (Derrida 1967, 1972; Mitosek 1988, s. 87; Wasilewska 2008, s. 109). Od punktu widzenia narratora czy perspektywy jest zależny opis lub wypowiedź człowieka na temat danej sytuacji. Jest on obserwatorem zaistniałej sceny, którą na podstawie swoich spostrzeżeń komentatorskich interpretuje w sobie właściwy sposób. W wykreowanym świecie dziecka ono będzie narratorem, a odbiorca badaczem reinterpretującym przedstawioną przez nie rzeczywistość. Świat stworzony będzie zależeć od tego, jak mały człowiek będzie się orientować w przestrzeni, rozmieszczeniu punktów odniesienia, interpretacji osobniczej relacji usytuowanych w przestrzeni przedmiotów, kierunku oglądu i wzajemnego stosunku między podmiotem i przedmiotem obserwacji (Niesporek-Szamburska 2009, s. 160-161).

Świat fikcji powstaje na podstawie znanych nam językowych ujęć, dostępnych dla każdego członka danej kultury. Niestety nawet przy ich pomocy, a bez udziału 
autora dotarcie do tego świata jest niemożliwe. Doskonale tę problematykę pokazują powstałe w trakcie zajęć rysunki. Żaden z nich nie jest dosłowny. Przykładami służyć mogą prace: Mai, Sonii i Wiktora. Sześcioletnia Maja narysowała kobietę w sukni balowej. Rysunek można zinterpretować bezproblemowo. Nie znamy jednak elementów znaczących, ukrytych pod tym przedstawieniem. Dopiero podczas rozmowy z autorką otrzymałem dostęp do jej świata fikcji, fantazji, znaczenia. Wyjawiła mi w sekrecie, „na ucho”, że narysowała księżniczkę, bo zawsze chciała nią być. Cały akt graficzny okazał się zapisem jej marzenia. Ośmioletnia Sonia natomiast narysowała trupią czaszkę, a dziewięcioletni Wiktor smoka, co można było łatwo zinterpretować. W przypadku braku możliwości rozmowy i spotkania $\mathrm{z}$ autorami nigdy bym się nie dowiedział, że są to rysunki przedstawiające ich tatuaże. Tym samym ukryty element znaczący zostałby utracony, a reprezentacje graficzne określone dosłownie.

Przełożenie ujęcia językowego na graficzną formę komunikacji niesie ze sobą pewną gamę następstw formalnych w konstrukcji tworzonego świata. „Formy graficzne nie przedstawiają swoich elementów kolejno, lecz równocześnie" (Tomaszek 2006, s. 131). W trakcie ich wykonywania autor nie ma możliwości naniesienia poprawek, uzupełnień, aby np. rysunek był zrozumiały dla odbiorcy. „Dziecko, rysując, zakłada, że oglądający będzie umiał zinterpretować przedstawioną reprezentację. W procesie rysowania można dopatrywać się zatem specyficznego związku graficzno-werbalnego. Wypowiedź słowna może uzupełniać obraz lub go wzbogacać, ułatwiając wybór i organizowanie informacji z uwzględnieniem istotnych aspektów sytuacji” (Tomaszek 2006, s. 131). „....reprezentacja graficzna nie jest w pełni ukonstytuowana jako system komunikacji”" (Tomaszek 2006, s. 133). Jest ona bardziej osobista, zindywidualizowana. Końcowy akt graficzny jest sumą cech charakterystycznych przedmiotu i rysującej go osoby.

Niezrozumienie dzieł dzieci potęgowane jest przez inne podejście do rzeczywistości przedstawianej. Powstają one na bazie bliższych związków małych autorów z przedmiotami i światem. Najmłodsi twórcy skupiają się na istocie rzeczy, otaczającej rzeczywistości i aktualnym znaczeniu, a nie na cechach wizualnych swojej pracy. Dzieci skupiają się raczej na przeżyciach, jaki przedmiot w nich wywołuje, a tworzone znaki określają sens jego wiedzy na temat swojego otoczenia, własnych doświadczeń i oczekiwań (Szymańska 2007, s. 201-202).

W zebranym przeze mnie materiale uwidacznia się powyższy element. Dla dzieci ważniejsze jest to, co rysunek przedstawia, niż to, jak jest narysowany. Przykładem może być praca wspomnianej wcześniej Mai. Jej księżniczka nie zmieściła się na kartce. Podobny problem miał jej równolatek Michał. Wykonał on najszybciej $\mathrm{z}$ całej grupy swoją pracę przedstawiającą wiele postaci. W momencie, gdy oddawał swój obrazek, stwierdził, że dorysuje jeszcze biedronkę, wskazując miejsce, gdzie to zrobi (było to pole wielkości 2 na $3 \mathrm{~cm}$ ). Michał wykorzystał kartkę w całości, choć twierdził, że narysuje małą biedronkę, taką, która by się zmieściła na poprzednim 
rysunku. Bliskiego związku dzieci z przedmiotami można było doświadczyć w pracy Sonii i Wiktora, którzy narysowali swoje tatuaże.

Na efekt końcowy twórczość dziecka ma wpływ to, jak ono widzi. Po porodzie, ze względu na fizyczne właściwości wzroku, świat postrzega do góry nogami. „Następnie uczy się patrzeć i widzi tyle, ile wie o danej rzeczy. Dlatego np. rolnik, patrząc na pole, będzie widział, kiedy pszenica jest dojrzała i należy ją skosić, inżynier zaś będzie widział w danej konstrukcji, jakie jest jej rozwiązanie techniczne, a artysta zobaczy świat tysiącami kolorów i barw, zupełnie inny i nieznany innym ludziom" (Karczmarzyk 2007, s. 316).

Bardzo ważnym elementem w powstających formach reprezentacji graficznych jest tło. Małgorzata Karczmarzyk tę problematykę omawia przy pomocy terminu „puste znaczące rysunku”, „Z punktu widzenia sensu stricto semiotycznego «puste znaczące rysunku» to czyste, nienarysowane tło" (Karczmarzyk 2008, s. 39). Przestrzenie te mają znaczenie dla autora lub znaczą o nim i są one znaczące dla całości utworu. W przypadku dzieci „puste znaczące rysunku” w ich przedstawieniach graficznych może pełnić funkcję komunikacyjną albo akomunikacyjną. Białe tło może być barierą między osobą a otoczeniem. Interpretuje się je jako ucieczkę do środka własnych problemów i nieuświadomionych emocji, często oceniając negatywnie. Z badań Małgorzaty Karczmarzyk wynika, że białe tło jest wynikiem beztroski, niezrozumienia, „dlaczego powietrze ma mieć jakiś kolor, skoro jest przezroczyste?” (Karczmarzyk 2008, s. 39-44). Wynikiem negatywnego odbioru takich prac są schematy, według których postępujemy. Dzieciom narzucane są kolory i to jak powinien być wykonany rysunek. Nagradzane i pozytywnie są oceniane, gdy wykonają go w myśl schematu dorosłych, czyli według Karczmarzyk „znaczących innych”. Każde dziecko chce być akceptowane i chwalone. Powoduje to, że uczą się one reguł oraz jednego słusznego kodu przekazu, którym chcą się porozumiewać ze światem dorosłych ludzi. „Kod ten (tj. rysunkowy, sic!) stanie się zaś dopiero wtedy rozpoznawalny, kiedy będzie na tyle jednolity i jasny, a może nawet schematyczny, że my dorośli będziemy potrafili go odczytać i zrozumieć - tylko czy wtedy będzie on jeszcze twórczy?" (Karczmarzyk 2008, s. 43-45).

Opisana wyżej problematyka znalazła swoje odzwierciedlenie w zebranym przez mnie materiale. W większości prac tło było czyste, nienarysowane. Wyjątkiem był rysunek najstarszej dziewczynki, dziesięcioletniej Marty, która narysowała scenę polowania, dobierając specjalnie trzy kolory (żółty i dwa odcienie brązu). Barwy i przedstawiona historia miały oddawać „klimat” obrazów pradziejowych.

Na prace wykonane przez dzieci mają wpływ „znaczący inni”. „Środowisko artystyczne obejmuje bowiem tak zwane osoby znaczące, stanowiące wzór osobowy, czyli tzw. mentorów” (Jakubiec 2006, s. 41). „Mentorem nazywamy kogoś, kto sprawując indywidualną opiekę nad przyszłym twórcą, steruje jego rozwojem, dora-

\footnotetext{
${ }^{4}$ To ,element znaczący bez elementu znaczonego”.
} 
dza i chroni przed niebezpieczeństwami” (Nęcka 2001, s. 153). Zostać nim może osoba o wysokim statusie społecznym i będąca ekspertem w danej dziedzinie. Mentor wspiera i rozwija talent danej jednostki m.in. przez przekazywanie niepisanych reguł rządzących się daną dziedziną. „Często [...] mentor jest równocześnie modelem, czyli wzorcem osobowym. Modelowanie jest jedną z metod wychowania, [...] polegającą na dostarczeniu sposobności do obserwowania określonego zachowania innych (modeli)" (Jakubiec 2006, s. 41). Powyższe elementy najprawdopodobniej kształtują każdego artystę. „...można wręcz zaryzykować twierdzenie, iż każdy wybitny człowiek, w tym artysta, spotkał na swojej drodze życiowej jakiegoś mentora, bez którego rozwój talentu twórczego nie byłby możliwy" (Jakubiec 2006, s. 42). Dzieci w okresie ideoplastyki mimo silnego wpływu „znaczących innych” „myślą jeszcze w sposób magiczny, co znajduje odzwierciedlenie w ich obrazkach: dlaczego na rysunku rodziny musi pojawić się siostra. Skoro przecież to takie przyjemne, że choć raz można ją pominąć - i tak zawsze znajduje się w centrum uwagi? Dlaczego bratu trzeba domalować dłonie, skoro nieustanie zabiera on siostrze różne przedmioty z biurka, które nigdy już do niej nie wracają?" (Szymańska 2007, s. 199).

Powyższe najprawdopodobniej również znalazło swoje odzwierciedlenie w wynikach badań. W trakcie prezentacji pokazanej w pierwszej części zajęć wspomniałem, że najbardziej podobają mi się ryty przedstawiające strusie. Nie wiem, czy jako prowadzący zajęcia stałem się ,znaczącym innym”, ale strusia obok słonia i jelenia narysowała dziesięcioletnia Matylda.

\section{ZAKOŃCZENIE}

Język, będąc podstawą danego świata, jest jedynym filarem jego stworzenia. Nie określa on rzeczywistości obiektywnie, ale daje możliwość poruszania się w niej i prowadzenia jakichkolwiek rozważań, w tym tych zwanych naukowymi. Przedstawione zagadnienia dotyczące twórczości dzieci oraz badania pokazują, że język ma bardzo duże znaczenie i dla tworzenia, i dla interpretacji sztuki. Przekazywany jest on w drodze socjalizacji, co powoduje, że jednostka myśli w taki sam sposób jak grupa, znajduje i stosuje określone słowa i ich sens, te natomiast określają w dużej mierze jej dostęp do otaczającego świata. Powoduje to, że w twórczości dzieci możemy odnaleźć wiedzę o autorze, jak i społeczności. Nie jest ona dla osoby interpretującej dostępna. Dzieje się tak, ponieważ ze świata rzeczywistego nie ma dostępu do świata fikcji. Przyczyną tego jest indywidualny, jednostkowy charakter jego kreacji. Stworzony świat będzie zależeć od tego, jak mały autor orientuje się w przestrzeni. W odbiorze twórczości dzieci istotna jest też wiedza interpretatora. Zależeć ona będzie od punktu jego obserwacji, kultury, w jakiej został wychowany, a także jego własnych przeżyć. Zakładając nawet, że jesteśmy przedstawicielami danej kultury, a dzięki temu znane nam jest dane ujęcie językowe, to nawet przy jego pomo- 
cy, a bez udziału autora dotarcie do owego świata fikcji, znaczenia, znaczeń jest niemożliwe. Przekładając powyższe na temat sztuki naskalnej uważam, że w prawie wszystkich przypadkach nie będziemy w stanie odczytać komunikatu zawartego w rytach czy malowidłach naskalnych. Spowodowane jest to tym, że dla większości obrazów sztuki naskalnej nie mamy dostępu do kultury, a co za tym idzie języka twórców. Niemożliwe jest też porozmawianie z autorem danego „dzieła”. Ponadto interpretującego dzieli od wybranego przedstawienia sztuki naskalnej duży dystans czasu.

Przywołane wybrane zagadnienia teoretyczne dotyczące rysunków dzieci pokazują też pewne cechy kształtujące „wypowiedź artystyczną”. Najmłodsi zakładają, że odbiorca będzie umiał zinterpretować ich pracę. Formy graficzne nie przedstawiają swoich elementów kolejno, lecz równocześnie. Biorąc pod uwagę również te elementy w kontekście interpretacji sztuki naskalnej, zyskujemy następne argumenty, które udowadniają jak skomplikowane i niedostępne jest dla nas znaczenie tamtych „dziel”.

Rysunki dzieci i „sztukę naskalną” różni kilka elementów. Przede wszystkim te „formy twórcze” są wykonane odmiennymi technikami, przy pomocy różnych narzędzi. Powstają także na innym podłożu. Mali twórcy skupiają się na istocie rzeczy, otaczającej rzeczywistości i aktualnym znaczeniu, a nie na cechach wizualnych swojej pracy. W przypadku sztuki naskalnej nie możemy tego jednoznacznie stwierdzić.

Przedstawione wybrane aspekty teoretyczne poświęcone analizie twórczości dzieci pokazały, jak skomplikowany jest proces powstawania i interpretacji sztuki, sztuki naskalnej, której znaczenia w większości przypadków nie jesteśmy w stanie poznać. Powyższe jest tylko jedną z możliwości przeniesienia tematyki poświęconej dziełom najmłodszych na grunt sztuki naskalnej. Teoria i badania skupiające się na „wyrazie artystycznym” prac dzieci może posłużyć do pokazania tego, jak wiele znaczeń mogą kryć w sobie ryty i malowidła naskalne. Cel ten realizowany będzie na dwóch płaszczyznach. Pierwszej - pokazującej elementy wpływające i kierujące autorem, a co się z tym wiąże na przekazywane w sztuce wartości. Drugiej - wykorzystującej prace dzieci jako bazę przykładów możliwości nadania znaczenia. W ramach pierwszej płaszczyzny zostały przedstawione takie elementy, jak: „znaczący inni”, problematyka oceny pracy i zabawa jako motyw działania. Wymienione wartości mogły mieć wpływ na kształtowanie znaczenia sztuki naskalnej, a także powodować jego zmianę. $Z$ racji tego są istotne dla poszukiwań ukrytych $\mathrm{w}$ nich sensów. W drugiej płaszczyźnie, opartej na opisanym badaniu pilotażowym, zebrany materiał wykazał, że nie ma dwóch podobnych prac pod względem wykonania i zastosowanych elementów. Autorzy chcą natomiast przedstawić w nich takie same wartości: chęć podzielenia się wiedzą, marzeniami; pokazania otaczającej rzeczywistości; scen z życia; istotnego wydarzenia, przedmiotu, znaku dla danej osoby. Kompilacja analizy wykonania, zastosowanych elementów i wartości w twórczości dzieci, połączona z nowymi danymi pozyskanymi przy pomocy rozbudowanych 
badań, mogą dać w przyszłości szeroką bazę prawdopodobnych znaczeń sztuki naskalnej. Przytoczone wyżej elementy potwierdzają, że mamy do czynienia z wieloma „książkami”, których nigdy nie uda nam się odczytać, bo każdy z twórców posiadał, mimo tego że ujednolicony, to jednak indywidualny sposób zapisu i nadania znaczenia. Tym samym nigdy nie będziemy mieć pewności, czy nadane przez nas wartości rytom, malowidłom naskalnym są właściwe bez konsultacji z autorem. Omówione zagadnienia mogą posłużyć do analizy sztuki naskalnej jako rezerwuar do poszukiwań możliwych znaczeń.

W związku z powyższymi wnioskami mam wątpliwości co do jednoznacznych stwierdzeń $\mathrm{w}$ badaniach naukowych, że dane przedstawienie sztuki naskalnej powstało na drodze np. szamanizmu czy magii sympatycznej. Jest to niemożliwe do zweryfikowania ${ }^{5}$.

Na bazie tego, co napisałem wyżej, celem powstałego podejścia nie będzie tłumaczenie, interpretacja przedstawień, a pokazanie tego, jak bardzo złożone są to konstrukcje znakowe. Dalsze badania nad sztuką naskalną w kontekście rysunków dzieci uważam za bardzo obiecujące. Mimo różnic, widzę wiele elementów łączących jeden i drugi typ tworzenia przedstawień znakowych. Podstawą takiego stwierdzenia są podobne konstrukcje kształtowania wyrazu myśli, wynikające ze specyfiki komunikacji graficznej.

Przywołana problematyka wymaga poszerzenia w zakresie literatury, jak i przeprowadzenia badań na większej grupie osób. W przyszłości rozbudowane studia w tym zakresie mogą przynieść argumenty w postaci danych statystycznych, które będą istotne w dyskusji na temat: znaczenia, tworzenia typologii, datowania na podstawie przedstawień o znanym wieku lub ramach czasowych i relacji względem innych analogicznych wizerunków, w zakresie sztuki naskalnej.

\section{BIBLIOGRAFIA}

Bednarik G.R.

2008 Children as Pleistocene artists. Rock Art Research, 25(2), s. 173-182.

Bower B.

2007 Children of Prehistory: Stone Age Kids Left Their Marks on Cave Art and Stone Tools. Science News, 171(17), s. 264-266.

Clottes J., Lewis-Williams D.

2009 Prehistoryczni szamani. Trans i magia w zdobionych grotach. Warszawa: Wydawnictwa Uniwersytetu Warszawskiego.

Consens M., Bello M.A., Rodríguez G.

2002 Rock Art and Education in Uruguay: What Did the Children Say? Purakala, 11(1-2), 12(1-2), s. 69-76.

\footnotetext{
${ }^{5}$ Wyjątkiem będą badania poświęcone sztuce naskalnej, gdzie dysponujemy poza samym przedstawieniem źródłami innego rodzaju, dzięki którym możemy poznać znaczenie.
} 
Cue Villate V., Fernandez Ortega R.

2006 ¿Quienes hicieron los dibujos en las cuevas? Havana: Ediciones Extramuros.

Derrida J.

1967 De la grammatologie. Paris: Minuit.

Derrida J.

1972

Positions. Paris: Minuit.

Golka M.

2004 Pojmowanie zabawy. W: J. Grada, H. Mamzer (red.), Karnawalizacja. Tendencje ludyczne w kulturze współczesnej (s. 20). Poznań: Wydawnictwo Naukowe UAM.

Huizinga $\mathrm{J}$.

2007 Homo ludens. Zabawa jako źródło kultury. Warszawa: Wydawnictwo Aletheia.

Jakubiec S.

2006 Współczesne wzorce osobowe: mentor i model w wychowaniu przez sztukę. W: K. Krasoń, B. Mazepa-Domagała (red.), W kręgu sztuki i ekspresji dziecka. Rozważania inspirujace (s. 41-42). Mysłowice - Katowice: Wydawnictwo: Górnośląska Wyższa Szkoła Pedagogiczna im. Kardynała Augusta Hlonda.

Jolly P.

2003 Conservation of Rock Art in Lesotho, Southern Africa: A Project to Educate Primary School Children Concerning the Need to Preserve San Rock Paintings. International Newsletter on Rock Art, 35, s. 17-18.

Karczmarzyk M.

2006 Rozumienie „znaczeń” w rysunku małego dziecka - czyli jak postrzegane są wytwory plastyczne dzieci przez dorosłych: artystów pedagogów, socjologów. W: K. Krasoń, B. Mazepa-Domagała (red.), W kręgu sztuki i ekspresji dziecka. Rozważania inspirujące (s. 126). Mysłowice-Katowice: Wydawnictwo: Górnośląska Wyższa Szkoła PedagoKarczmarzyk M. giczna im. Kardynała Augusta Hlonda.

2007 Twórczość plastyczna dziecka w świetle współczesnych poglądów, będąca inspiracją dla drogi twórczej. W: K. Krasoń, B. Mazepa-Domagała (red.), Oblicza sztuki dziecka w poszukiwaniu istoty ekspresji (s. 316). Katowice - Mysłowice: Wydawnictwo: Górnośląska Wyższa Szkoła Pedagogiczna im. Kardynała Augusta Hlonda.

Karczmarzyk M.

2008 „Puste znaczące rysunku” jako różne reprezentacje graficzne tła w twórczości plastycznej dzieci i dojrzałych artystów. W: E. Szatan, D. Bronk (red.), Gdyby Einstein wspótcześnie chodzit do szkoły... Dziecko i twórczość w pedagogice wczesnoszkolnej (s. 39-45). Gdańsk: Wydawnictwo Uniwersytetu Gdańskiego.

Mannheim K.

1992 Ideologia i utopia. Lublin: Wydawnictwo Test.

Mitosek Z.

1988 Mimesis krytyczna. Pamiętnik Literacki, 3, s. 87.

Nęcka E.

2001 Psychologia twórczości. Gdańsk: Gdańskie Wydawnictwo Psychologiczne.

Niesporek-Szamburska B.

2009 Perspektywa językowego oglądu świata w twórczości dziecięcej. W: K. Krasoń, M. Łączyk (red.), Odkrywanie - wyjaśnianie rzeczywistości. Perspektywa artystyczna i edukacyjna (s. 160-161). Katowice: Oficyna Wydawnicza Wacław Walasek.

Rozwadowski A.

2009 Obrazy z przeszłości. Hermeneutyka sztuki naskalnej. Poznań: Wydawnictwo Naukowe UAM. 
Sharpe K., Lacombe M., Fawbert H.

2002 Investigating finger flutings. Rock Art Research, 19(2), s. 109-116.

Sharpe K., Van Gelder L.

2004a Children and Paleolithic art: Indications from Rouffignac Cave, France. International

Sharpe K., Van Gelder L.

Newsletter on Rock Art, 38, s. 9-17.

2004b Trois formes de TracÉs digitaux (OU Sevérines) en Grotte de Rouffignac, France. Préhistoire du Sud-Ouest. [Artykuł dostępny na stronie: http://ksharpe.com/word/AR60.htm].

Sharpe K., Van Gelder L.

2005 Techniques for studying finger flutings. Society of Primitive Technology Bulletin, 30, s. 68-74.

Sharpe K., Van Gelder L.

2006a Evidence for cave marking by Palaeolithic children. Antiquity, 80(310), s. 937-947.

Sharpe K., Van Gelder L.

2006b Finger flutings in Chamber A1 of Rouffignac Cave, France. Rock Art Research, 23(2), s. 179-198.

Sharpe K., Van Gelder L.

2006c The study of finger flutings. Cambridge Archaeological Journal, 16(3), s. 281-295.

Sharpe K., Van Gelder L.

2010 Four forms of finger flutings as seen in Rouffignac Cave, France. W: P. Bahn (red.), An enquiring mind: Studies in honor of Alexander Marshack (s. 269-285). Oxford: Oxbow Books.

Stapert D.

2007 Finger Flutings by Palaeolithic Children in Rouffignac Cave: Comments on a Paper by

Strzemiński W.

Sharpe \& Van Gelder. Antiquity, Project Gallery, 81(312).

1974 Teoria widzenia. Kraków: Wydawnictwo Literackie.

Szczepska-Pustkowska M.

2008 Zabawa jako przestrzeń dziecięcej twórczości (czyli o pewnym eksperymencie pedagogicznym). W: E. Szatan, D. Bronk (red.), Gdyby Einstein wspótcześnie chodził do szkoty... Dziecko i twórczość w pedagogice wczesnoszkolnej (s. 137-143). Gdańsk: Wydawnictwo Uniwersytetu Gdańskiego.

Szymańska M.

2007 Przebieg procesu twórczego na podstawie obserwacji dzieci rysujących. W: K. Krasoń, B. Mazepa-Domagała (red.), Oblicza sztuki dziecka - w poszukiwaniu istoty ekspresji (s. 199-202). Katowice - Mysłowice: Wydawnictwo: Górnośląska Wyższa Szkoła Pedagogiczna im. Kardynała Augusta Hlonda.

Tomaszek M.

2006 Graficzne definiowanie pojęć przez dzieci w wieku czterech i sześciu lat. W: K. Krason, B. Mazepa-Domagała (red.), W kręgu sztuki i ekspresji dziecka. Rozważania inspirujace (s. 131-133). Mysłowice - Katowice: Wydawnictwo: Górnośląska Wyższa Szkoła Pedagogiczna im. Kardynała Augusta Hlonda.

Van Gelder L.

2012 Ten Years in Rouffignac: A Collective Report on Findings from a Decade of Finger Flutings Research. L'art pléistocène dans le monde. Actes du Congrès IFRAO, CD, s. $377-388$. 
Wasilewska A.

2008 Światy możliwe narracji dziecięcych. W: E. Szatan, D. Bronk (red.), Gdyby Einstein wspótcześnie chodził do szkoły... Dziecko i twórczość w pedagogice wczesnoszkolnej (s. 101-109). Gdańsk: Wydawnictwo Uniwersytetu Gdańskiego.

\title{
LOOKING FOR THE MEANINGS OF ROCK ART THROUGH THE RESEARCH ON CONTEMPORARY CHILDREN'S ART
}

\begin{abstract}
Summary
With the interest in rock art came a search for its meaning. My accidental encounter with literature analysing drawings of today's children resulted in an attempt to look at the rock art through the prism of studies on the works of the little ones. Perceived common problems inspired me to conduct a pilot study, which sought to establish whether classes with children and issues transposed from the meanings of their drawings can be significant for the study of rock art.

Pilot studies have confirmed the usefulness of the transposition of the theory relating to the analysis of children's drawings on the ground of rock art, on the understanding that its formation was shaped by values similar to those shaping works of children. Due to the multitude of meanings in children's paintings, the specifics of the worlds of fiction, fantasies, to which - for linguistic reasons - we have no access, we may comprehend a given representation only through the author. Maja's, Sonia's and Wiktor's works all provide interesting examples. Maja drew a woman dressed in a ball gown. We do not know, however, the signified hidden under the representation. Only after a conversation with the author did I learn that the drawing represented a princess, and the whole act is a graphic image of the girl's dreams. Sonia drew a skull and Viktor - a dragon, easily decipherable. Yet, had it not been for the discussion and a personal encounter with the authors, I would have never found out that these are drawings showing their tattoos. Thus, the hidden signified would have been lost and the signifier read literally. These examples show that what we have is a number of 'books' that are never going to be deciphered, because despite using a necessarily standardised notation and way of attributing meaning, each author had his or her individual way of doing things. Thus, we will never be certain whether the meaning we assign is correct. The conclusions drawn from the quoted literature and my research, which definitely needs to be broaden, make me wary of unequivocal statements claiming that that behind a given rock art representation was, e.g., shamanism or sympathetic magic. This, in most cases, is impossible to verify, and children's works show graphical representations may contain any unlimited reservoir of content that can be used in a search for rock art meanings.

The issue is still pending further research: extensive study of literature and tests on a larger group of people. In the future, extensive studies on the subject may provide statistical data, possibly offering sound arguments for the discussion on the importance of constructing typologies, dating based on representations of known age or time frame and relation to other, similar images in the field of rock art.
\end{abstract}

